\title{
The role of parvovirus B19 and the immune response in the pathogenesis of acute leukemia
}

Running title: Parvovirus B19 and the pathogenesis of acute leukemia

Jonathan R Kerr, ${ }^{1}$ Derek L Mattey ${ }^{2}$,

${ }^{1}$ Escuela de Medicina y Ciencias de la Salud, Universidad del Rosario, Quinta de Mutis, Bogotá, Colombia;

${ }^{2}$ Staffordshire Rheumatology Centre\& University of Keele, Haywood Hospital, Stoke on Trent, United Kingdom.

Correspondence to: Jonathan R Kerr, Escuela de Medicina y Ciencias de la Salud, Universidad del Rosario, Quinta de Mutis, Bogotá 111221, Colombia. Email: jonathan@ssl-mail.com

\section{Conflict of interest}

Neither Jonathan Kerr, nor Derek Mattey, has any conflict of interest with regard to the content of this article. 


\section{List of abbreviations}

ALL; acute lymphoblastic leukemia

AML; acute myeloblastic leukemia

CML; chronic myeloblastic leukemia

LGLL; large granular lymphocyte leukemia

CTCL; chronic T cell lymphocytosis

GM-CSF; granulocyte-macrophage colony stimulating factor

HVR; hypervariable region

IVIG; intravenous immunoglobulin

NS1; nonstructural protein 1

Word count: 4,862 


\section{Abstract}

In this article, we review the evidence suggesting a possible role for B19 virus in the pathogenesis of a subset of cases of acute leukemia. Human parvovirus B19 infection may complicate the clinical course of patients with acute leukemia, and may also precede the development of acute leukemia by up to 180 days. Parvovirus B19 targets erythroblasts in the bone marrow, and may cause aplastic crisis in patients with shortened red cell survival. Aplastic crisis represents a prodrome of ALL in $2 \%$ patients. There is significant overlap between those HLA class I and II alleles which are associated with a vigorous immune response and development of symptoms during B19 infection, and those HLA alleles which predispose to development of acute leukemia. Acute symptomatic B19 infection is associated with low level of circulating IL-10 consistent with a vigorous immune response; deficient IL-10 production at birth was recently found to be associated with subsequent development of acute leukemia. Anti-B19 IgG has been associated with a particular profile of methylation of human cancer genes in patients with acute leukemia, suggesting an additional hit and run mechanism. The proposed role for parvovirus B19 in the pathogenesis of acute leukemia fits very well with the delayed infection hypothesis and with the 2-step mutation model, which describes the carriage of the first mutation prior to birth, followed by suppression of haematopoiesis, which allows rapid proliferation of cells harbouring the first mutation, acquisition of a second activating mutation, and expansion of cells carrying both mutations, resulting in a clinical presentation of acute leukemia.

Keywords: Human parvovirus B19, acute leukemia, acute lymphoblastic leukemia, acute myeloblastic leukemia, cytopenia, erythrotropism, aplastic crisis, pancytopenia, HLA, cytokine. 


\section{Introduction}

Acute childhood leukemia accounts for most cases of childhood cancer and its cause, or causes, are not yet understood, although modern treatment regimens are often successful. Many candidate environmental exposures have been proposed, however, most of these lack epidemiological evidence and plausible biological mechanisms. Significant evidence supports the role of infection and immunity in the pathogenesis of acute childhood leukemia, however, it is not clear whether one or more infectious agents are involved[1].

Human parvovirus B19 is a single-stranded DNA virus which replicatesprimarily in the erythroblasts in the bone marrow and it has been shown to persist life-long in many different cell types throughout the body following acute infection[2]. B19 infection commonly causes erythema infectiosum, arthralgia, fetal death, transient aplastic crisis in patients with shortened red cell survival, and persistent infection in immunocompromised persons. Less common clinical manifestations include atypical skin rashes, neurological syndromes, cardiac syndromes, and various cytopenias resulting from bone marrow infection[2,3].

B19 infection has also been demonstrated to occur in the setting of acute leukemia. This has been thought to represent either reactivation of latent B19 virus due to immunosuppression or due to coincidental acquisition of B19 virus in the context of acute leukemia during cytotoxic treatment. But more interestingly, there have been a significant number of case reports of acute leukemia with documented acute B19 infection occurring either before or at the time of diagnosis of acute leukemia, suggesting the possibility that B19 virus may contribute to the pathogenesis of acute leukemia in some way.

In this review, we review all published cases of B19 infection associated with acute leukemia, occurring both before and after the diagnosis of acute leukemia, studies of B19 infection in leukemia, parallels between the pathogenesis of acute leukemia and that of B19 infection, the particular features of B19 infection which highlight its potential as a candidate trigger infection in the pathogenesis of acute leukemia, consideration of 
other childhood virus infections which have been associated with acute leukemia, and recommendations for future research.

\section{Case reports of B19 infection in patients with acute leukemia during chemotherapy}

Table 1 summarises the clinical course of 29 patients with acute leukemia in whom B19 infection was documented during chemotherapy. The age range of these patients was $1-65$ years, with 13 males, 15 females and one of unknown sex. There were 17 patients with acute lymphoblastic leukemia (ALL), 2 patients with B cell ALL, 6 patients with pre-BALL, one patient with acute myeloblastic leukemia (AML) type M6b, 2 patients with LGLL and one patient with CTCL. The interval between diagnosis of leukemia and onset of B19 infection ranged from 14 days to 14 years. B19 infection resulted in some degree of anemia in all patients, which ranged from mild to severe; thrombocytopenia was documented in 13 patients, lymphocytopenia in one patient and neutropenia in 2 patients. B19 infection was not treated in 5 patientsand treatment was undisclosed for 2 patients. Five patients received intravenous immunoglobulin (IVIG) alone, while 8 patients received both IVIG and red cell transfusion. Five patients received red cell transfusion alone, while 3 patients were treated by stopping chemotherapy. There were no deaths due to B19 infection and all patients recovered with or without specific treatment.

\section{Case reports of B19 infection in patients with acute leukemia prior to or at the time of diagnosis}

Table 2 summarises the clinical course of 16 patients with acute leukemia in which B19 infection was documented prior to or at the time of diagnosis of acute leukemia. There were 6 males and 10 females. Among 15 of the 16 patients, the ages ranged from 1 to 33 years, and the $16^{\text {th }}$ patient was 69 years old. There was a B19-associated prodrome consisting of aplastic crisis in 7 of 16 patients which occurred $14-180$ days prior to 
the diagnosis of leukemia.Detection of B19 infection in the remaining 9 patients without a prodrome of aplastic crisis, occurred $0-3$ days before the diagnosis of acute leukemia. All 16patients except one (No. 3) had anemia at presentation, which ranged from mild to severe. Patient no. 3 also stands out as having a different clinical presentation from the others, in that this was the only patient to present with neurological symptoms.

Evidence of acute B19 infection at presentation consisted of detection of either anti-B19 IgM or DNA, or both, except in the case of patient no. 10, who did not have specific B19 testing performed. However, this case had a prodrome of aplastic crisis, a rash resembling erythema infectiosum, anemia, erythroid hypoplasia on bone marrow testing, and other presenting symptoms typical of B19 infection. Bone marrow was examined in 13 of 16 cases, and each of these 13patientsexhibited at least one of the following recognized signs of B19 infection; erythroid hypoplasia, pancytopenia and giant pronormoblasts. Regarding treatment for B19 infection, 4 patients received red cell transfusion, 4 patients received both platelet and red cell transfusions, one patient received IVIG alone and 7 patients received no treatment. In 3 cases, outcome was not stated; among the remaining 13 patients, there were 4 deaths which were due to relapse $(n=1)$, secondary bacterial sepsis $(n=2)$, and idiopathic pneumonia syndrome $(n=1)$. The remaining 9 patients recovered.

\section{Studies of B19 infection in acute leukemia}

Table 3 summarises the results of various studies of B19 infection in acute leukemia. Where sufficient clinical details were included in these reports, specific patients were included in either Table 1 or Table 2, as appropriate.

Broliden et al [18] tested the bone marrow of 59 unselected children with malignancies by PCR to detect B19 DNA; 7 of 59 were positive, consisting ofALL on chemotherapy $(n=3)$ (in one of these 3 cases, the presence of B19 was not associated with symptoms; the other two cases have been included in Table 1 as patient numbers 16 and 17), ALL at onset $(n=1)$ (patient no. 2 in Table 2), Non-Hodgkin's lymphoma $(n=2)$ and Ewing's sarcoma 
$(n=1)$. Unfortunately, the total number of cases within each disease category of childhood malignancies was not available.

El-Mahallawy et al [35] tested 50 ALL patients with anemia and 34 ALL patients without anemia (both groups were on maintenance therapy) for evidence of B19 infection. B19 DNA was positive in 11 of 50 ALL with anemia (of which, 4 were $\operatorname{IgM}+$ ) compared with 2 of $34 \mathrm{ALL}$ without anemia (none were serum anti-B19 IgM positive). Serum anti-B19 IgG was detected in 19/50 (38\%) vs 15/34 (44\%).

Jitschin et al [36] studied malignant and non-malignant diseases for evidence of B19 infection at the time of admission. Of 24 ALL patients at the time of admission, 10 (41.6\%) were serum anti-B19 IgG positive, 1 (4.2\%) wasserum anti-B19 IgM positive and 16.7\% were B19 DNA positive in either serum or bone marrow.

Lindblom et al [37] documented bone marrow positivity for B19 DNA in 6/86 (7\%) ALL patients at diagnosis and 12/31 (39\%) ALL patients during or between chemotherapy. Of the 6 B19 DNA+ ALL patients at diagnosis, 4 had anemia and 5 had thrombocytopenia.

Soliman et al [38] documented B19 markers in 39 ALL patients and 20 patients with solid tumors, all undergoing chemotherapy and 30 normal controls. DNA was detected in $11 / 39,5 / 20$ and $0 / 30$, respectively. Serum anti-B19 IgG was detected in 26/39, 10/20 and 18/30, respectively. Anti-B19 IgM was detected in 0/39, $3 / 20$ and 0/30, respectively. Patients positive for B19 DNA had significantly higher frequency of anemia, treatment with red cell transfusion, and longer hospital stay than B19 DNA negative patients.

Zaki et al [39] demonstrated positivity for serum B19 DNA in 6 of 25 (25\%) hemolytic anemia in aplastic crisis, 0 of 20 hemolytic anemia without aplastic crisis, 6 of 20 acute leukemia patients during chemotherapy, 9 of 20 (45\%) recently diagnosed acute leukemia, and 0 of 20 normal controls. Serum IgM was detected in 9 of 25 (36\%) hemolytic anemia in aplastic crisis, 1 of 20 (5\%) hemolytic anemia without aplastic crisis, 7 of 20 (35\%) 
acute leukemia patients during chemotherapy, 10 of 20 (50\%) of recently diagnosed acute leukemia and 0 of 20 normal controls.

Zaki et al [40] demonstrated B19 DNA in serum and bone marrow of 9 of 48 (20\%) ALL patients during chemotherapy as compared withnone of the controls. Serum anti-B19 IgM was detected in 12 of 48 (26.7\%) ALL patients during chemotherapy as compared withnone of the controls, and IgG was detected in 18 of $48 \mathrm{ALL}$ patients during chemotherapy as compared with 2 of $20(10 \%)$ controls.

Da Costa et al [41] tested patients with ALL, AML and chronic myeloblastic leukemia (CML) at diagnosis for B19 DNA in bone marrow, and found positivity in 12 of 78 (15.4\%) ALL, 25 of 155 (16.1\%) AML and 3 of 16 (18.7\%) CML. Multiple genotypes were found. Of the 40 participants, 25 (62.5\%) were infected with genotype $1 \mathrm{a}$ and 15 (37.5\%) with genotype 3b; $12 / 40$ (30\%) of the leukemia patients were co-infected with genotypes $1 \mathrm{a}$ and 3b. In addition, a new B19 virusintergenotypic recombinant (1a/3b) and an NS1 non-recombinant genotype 1a were detected in one patient.

Heegaard et al [42] studied the serum of 65 patients with childhood ALL at onset for evidence of B19 infection and found none positive; one ALL patient was found to be positive for B19 DNA 5 months prior to diagnosis of ALL during an episode of pancytopenia. This case report has been reported in detail [32] and is included as patient no. 14 in Table 2.

Heegaard et al [43] studied 75 ALL patients, 48 B19 seronegative and 27 B19 seropositive. 4 of 48 B19 seronegative patients seroconverted, and exhibited viremia, which was associated with profound anemia and thrombocytopenia in all 4 patients.

Ibrahem et al [44] documented IgG positivity in 19/40 new ALL patients and 12/60 normal controls. There was no association between presence of serum anti-B19 IgG and antibody to P53, but there was a significant 
association between presence of serum anti-B19 IgG and the TEL-AML1 fusion gene (also known as ETV6RUNX1), as 10 (71.4\%) of TEL-AML1 positive cases were positive for anti-B19 IgG.

Kishore et al [45] studied 35 children with malignancy (22 acute leukemia and 13 lymphoma at presentation) and 34 children with solid tumors. Evidence of 6 active B19 infections were found (serum anti-B19 IgM positivity), of which 5occurred in ALL patients and one in a lymphoma patient.Among the five anti-B19 IgM positive patients, 2 were B19 DNA positive and in 2 cases, giant pronormoblasts were also seen in bone marrow.

Zaki et al [46] demonstrated B19 DNA in serum of 10 of 45 (22\%) ALL patients during chemotherapy, 18 of 40 (45\%) ALL of recent onset and 0 of 20 healthy controls. Serum anti-B19 IgM was detected in 14 of 45 (31\%) of ALL patients during chemotherapy, 20 of 40 (50\%) ALL patients of recent onset and 0 of 20 healthy controls. Serum anti-B19 IgG was detected in 18 of 45 (40\%) ALL patients during chemotherapy, 16 of 40 (40\%) ALL patients of recent onset, and 0 of 20 healthy controls.

As regards the interpretation of these studies, as B19 virus persists indefinitely in various tissues, including blood and bone marrow, following acute infection, the clinical significance of detection of B19 DNA in the absence of recognised B19-associated symptoms is not entirely clear. This is quite a different situation to the detection of B19 DNA in blood contemporaneous with the occurrence of B19-associated symptoms, such as aplastic crisis or erythema infectiosum, in those patients included in Table 2, for example, in which sufficient clinical data is provided to enable confirmation that the clinical course of each patient was significantly impacted by acute B19 infection.

\section{The pathogenesis of acute leukemia}


A significant body of research supports the role of infection in the pathogenesis of acute childhood leukemia, and especially ALL. There are two main proposed infectious pathogenetic mechanisms which overlap somewhat. First, that childhood leukemia may result from infection with a specific infectious agent introduced into a population without herd immunity [47]. And second, that delayed exposure to common infections during infancy and childhood results in an increased risk of common pre-B cell ALL in children who harbor genetic mutations that result in the creation of a leukemic clone [48]. Such clones may then proliferate and expand into ALL upon stimulation with infections that occur later, some time after birth. Although there are many reports which support both of these hypotheses, there have been few proposed specific molecular mechanisms [1]. This sequence is summarized diagrammatically in Figure 1.

A significant body of evidence supports the second hypothesis of Greaves[48], including epidemiological studies which used surrogate indicators of exposure to infections, including birth order, history of infections in individuals, attendance at day-care and play groups, and parental contacts with possible sources of infection in the workplace $[49,50]$. These studies have shown that reduced exposure in early life to common childhood infections, increases the risk of developing leukemia. It has been shown that population mixing is an important risk factor, which further strengthens the putative role for infection in the causation of childhood leukemia. It is hypothesized that delayed infection during infancy may be an important causal factor [1].

There are a few recorded clusters of childhood leukemia [50-52], however, the role of time-space clustering appears to be modest $[50,51,53,54]$.

There have been numerous studies of HLA associations in childhood acute leukemia[55]. Various class II HLA alleles have been shown to be risk factors for development of childhood acute leukemia, including HLADPB1*0201 [56] and HLA-DR53, which is linked to carriage of HLA-DRB1*04, *07 and *09 alleles [57]. The supertypic specificity HLA-DR53 is encoded by theHLA-DRB4 locus in the HLA class II region. There was a moderate allelic association with the most common allele in the HLA-DR53 group, HLA-DRB1*04, in the whole 
group that was stronger in males [57]. HLA-DRB1*15 and *16 have also been reported as predisposing alleles[58,59] and also HLA-DRB1*01 [60]. Interestingly, ancestral HLA analysis has shown that there are 2 clades regarding the HLA-DR gene polymorphisms, and that DRB $1 * 01, * 04, * 07, * 09, * 15$, and $* 16$ are grouped with DR4 and DR5, while DRB1*03, *08, *11, *12, *13 and *14 are grouped with DR3 [61]. Interestingly, HLADRB1 alleles $* 01, * 04, * 07, * 09, * 15$, and $* 16$ have a net positive charge within the first hypervariable region, while HLA-DRB1 alleles *03, *08, *11,*12,*13 and *14 have a net negative charge within this region. The significance of this is considered below.

Class I HLA associations with acute leukemia include HLA-B40 [62], HLA-A11, HLA-B38 and HLA-B49 [63]. Klitz et al[64] report a continuum of risk associations for HLA-A, HLA-B and HLA-DRB1, supporting the hypothesis that infection and the resulting immune response, is important in the pathogenesis of acute leukemia.

Recently, it has been shown that interleukin-10 secretion is severely deficient in children who grow up to develop leukemia [65]. IL-10 is a strong anti-inflammatory cytokine secreted by monocytes and lymphocytes and is important in the limitation of cell-mediated immune reactions.It has been shown that IL-10 production attenuated an increased risk for repeated respiratory infections during infancy and childhood associated with elevated T cell IL-5 production at birth[66].It is possible that children with dysregulated immunefunction at birth are at higher risk for developing leukemia due to constitutively lowerexpression of IL-10, a cytokine that attenuates inflammatory responses [67].

Several studies and case reports indicate that asmall sub-group of ALL patientsundergo a previous phase of aplasia, which precedes development of overt ALL by $2-9$ months $[68,69]$. This is almost always associated with infection and either remits spontaneously or responds to corticosteroids. In the few cases that have been studied, immunoglobulin or T cell receptor gene analysis have confirmed the presence of the leukemia, or preleukemic, cells during this aplastic phase $[70,71]$. 


\section{Pathogenesis of parvovirus B19 infection}

The pathogenesis of parvovirus B19 infection is complex, particularly when the less common clinical manifestations are included. Although the mechanisms are considered separately, clearly they donot occur separately in vivo, and during a single B19 infection, several of these mechanisms may be involved. Table 4 summarises the pathogenetic mechanisms which have been documented during parvovirus B19 infection.

B19 acquisition is usually by the respiratory route via aerosol droplet transmission from an acutely infected patient[75], however, B19 virus may also be transmitted parenterally by infected blood and blood products[74]. Initially, the virus is thought to multiply in the throat, leading to viremia on day 6 , with infection of erythroblasts in the bone marrow $[75,76]$. Local viral replication is important in most clinical manifestations, except arthralgia, as virus has not been isolated from affected joints. The nonstructural protein (NS1) has been shown to be cytotoxic and NS1 cytotoxicity is thought to account for thrombocytopenia and leucopenia occurring during B19 infection[72]. B19 infection of erythroblasts results in apoptotic killing of infected cells and reticulocyte arrest[72,73], and this is important in transient aplastic crisis in patients with shortened red cell survival, erythema infectiosum, hydrops fetalis, chronic pure red cell aplasia, and aplastic anemia and other cytopenias, and may also be important in the pathogenesis of acute leukemia. Specific anti-B19lgG is produced from day 16 and this coincides with appearance of erythema infectiosum and arthralgia[75,76], which are thought to be mediated by immune complex deposition, at least in part. Appearance of serum anti-B19 IgG controls the infection, allowing recovery of erythroid cell production[74].

A variety of autoantibodies are produced during acute B19 infection, including rheumatoid factor, antinuclear antibody, anti-keratin and anti-collagen II antibodies [84], and antiphospholipid antibody which has the same specificity as that produced in systemic lupus erythematosus [85]. 
Various class I and II HLA alleles are associated with occurrence of symptoms (principally arthralgia and rash) during parvovirus B19 infection. These were HLA-B49 and HLA-DRB1*01, *04, *07, *15 and *16 alleles [78,89]. In all symptomatic B19-infected subjects who carried the above HLA alleles, there was marked release of various cytokines, including TNF- $\alpha$, IFN- $\gamma$, IL-6, granulocyte-macrophage colony stimulating factor (GM-CSF) and chemokine (C-C motif) ligand 2 (CCL2), and low levels of IL-10[101,102]. The B19 NS1 protein upregulates IL-6 in hemopoietic and endothelial cells, and this is mediated by the NF-KB site in the IL-6 promoter[81].

In addition, in the setting of symptomatic B19 infection, production of antibody to the B19 nonstructural protein was associated with the IL-10 -819/-592*TA haplotype which mediates low IL-10 transcription [103].

Following acute infection, B19 virus persists in many different tissues, including skin, bone marrow, synovium, and liver, and it is believed that this is a life long phenomenon[104]. The possibility that the B19 genome may integrate into the human genome has been investigated, and although this has not been confirmed to occur in a similar fashion tothe integration of the related parvovirus, adeno-associated virus, the human genome does exhibit short footprints of the B19 genome in multiple human genes, the significance of which remains unclear [105].

It has recently been shown that a particular pattern of DNA methylation among a subset of cancer genes was associated with a history of parvovirus B19 infection as detected by serum anti-B19 IgG but not anti-B19 IgM [100]. This finding suggests that B19 virus infection may drive specific DNA methylation patterns in susceptible B precursor cells, thus contributing to the leukemogenic potential of these cells, and these changes may be retained even after control of the infection [100]. 


\section{Parvovirus B19 as a candidate viral trigger in the pathogenesis of acute leukemia}

We believe that parvovirus B19 is involved in the pathogenesis of a subset of cases of acute leukemia, and that B19 virus is one of a number of viral triggers. There are various features of parvovirus B19 which make it a candidate trigger infection in the pathogenesis of acute leukemia. The majority of the population becomes infected early in life in both developed and developing worlds, and so the possibility of delayed infection exists for B19 virus, as has been proposed as a possible mechanism in the pathogenesis of acute childhood leukemia[47]. Interestingly, in studies of B19 infection in childhood leukemia from Mansoura, Egypt, B19 seroprevalence of the normal controls was zero $[39,46]$ and $10 \%[40]$, respectively, which was much lower than B19 seroprevalence in cases of acute childhood leukemia, where it ranged from $40 \%-45 \%[39,40,46]$. The reasons for this apparent delay in occurrence of B19 infection during childhoodin these studies deservefurther attention.

B19 virus is erythrotropic and primarily targets erythroblasts in the bone marrow. However, it is also able to infect various other cell types. B19 infection may directly result in aplastic crisis in patients with shortened red cell survival, and this aplastic crisis has been shown to be a prodrome of ALL in $2 \%$ of patients[68,69]. There are 7 case reports in the literature of B19-associated aplastic anemia, occurring several months prior to the onset of acute leukemia [27-33] and the clinical course of these cases is summarized in Table 2.

Symptomatic B19 infection has been shown to be associated with HLA-B49 and HLA-DRB1*01, *04, *07, *15 and *16 alleles[78,89]. All symptomatic parvovirus-associated HLA-DRB1 molecules carry a neutrallycharged glutamine at position 10 and a positively charged lysine at position 12 of the first hypervariable region (HVR), conferring a net postive charge to this region.HLA-DRB1 molecules with a positively charged firstHVR, include $* 01, * 04, * 07, * 09, * 15$ and *16. These associations were demonstrated for both males and females. HLA-B49 [63] and the above HLA-DRB1 molecules with a positive charge in the first HVR, have been associated with development of childhood ALL[57-59,63]. In fourpublished cases of B19 infection present at the time of 
diagnosis of acute childhood leukemia, each patient carried at least one HLA-DRB1 allele with a positive charge in the first HVR[26]. Table 5 shows the net charge in this first HVR for all HLA-DRB1 molecules, and relates this to known class II associations in acute leukemia, symptomatic parvovirus B19 infection and B19-associated acute leukemia.

Acute symptomatic B19 infection has been associated with raised circulating levels of TNF- $\alpha$, IFN- $\gamma$, IL-6, GMCSF and CCL2, and low levels of IL-10; these pro-inflammatory cytokines remain at elevated levels for up to 3 years following the time of acute infection [101,102]. Proinflammatory cytokines have been shown to be elevated during the prodrome and onset of acute childhood leukemia, and ALL cells express multiple proinflammatory cytokine receptors. In addition, interleukin-10 secretion is severely deficient in children who grow up to develop leukemia [65]. Development of antibody to the parvovirus B19 nonstructural protein, which is associated with more severe courses of infection, has been associated with the IL-10 -819/-592*TA haplotype which mediates low IL-10 transcription [103]. This is consistent with a heightened immune response in a subset of parvovirus infected persons with particular genetic determinants, and this may also be important in the putative role for parvovirus B19 in the pathogenesis of acute leukemia.

It has recently been shown that a particular pattern of DNA methylation among a subset of cancer genes was associated with a history of parvovirus B19 infection as detected by serum anti-B19 IgG but not anti-B19 IgM [100]. This finding suggests that B19 virus infection may drive specific DNA methylation patterns in susceptible B precursor cells, thus contributing to the leukemogenic potential of these cells, and these changes may be retained even after control of the infection [100].

\section{Perspective: viral causes of cancer}


Several viruses have been shown to cause human cancer and these are therefore known as oncoviruses. These include Epstein-Barr virus, hepatitis B virus, hepatitis C virus, human T-cell lymphotropic virus, human papillomaviruses, Kaposi's sarcoma-associated herpesvirus (human herpesvirus 8) and Merkel cell polyomavirus (Table 6)[106,107]. Following acute infection, oncoviruses generally cause little or no disease or non-neoplastic diseases in their respective hosts, and persist indefinitely. Oncoviruses may have a genome consisting of DNA (Epstein-Barr virus), RNA and DNA (human T-lymphotropic virus and hepatitis B virus), or RNA (hepatitis C virus). Some oncoviruses persist as circular episomes or plasmids and replicate separately from host cell DNA (Epstein-Barr virus and Kaposi's sarcoma herpesvirus) while other oncoviruses integrate into the host genome (polyomavirus and papillomavirus). Direct viral oncogenicity involves insertion of viral genes into the host cell or enhancement of the activity of pre-existing proto-oncogenes in the host genome. Indirect viral oncogenicity involves chronic non-specific inflammation occurring over decades following acute infection[106,107].

Members of the Parvoviridae have a DNA genome and persist indefinitely following acute infection which may or may not be manifested clinically. Parvovirus B19 persists in many different erythroid and non-erythroid human tissues following acute infection, including bone marrow, colon, heart, skin, liver, lymphoid, synovial, testicular and thyroid tissues. However, the mode of persistence of B19 virus is not yet fully understood. The B19 NS1 protein has been shown to upregulate transcription of both IL-6 [81] and TNF- $\alpha$ [108], and an increased inflammatory response has been demonstrated in some of the above tissues in association with expression of either B19 mRNA or proteins [109].

Therefore, there are certain aspects of the life cycle of parvovirus B19 which could fit with those of an oncovirus. However, certain parvoviruses, such as the rat parvovirus $\mathrm{H}-1$, have been shown to be oncolytic in humans [110]. Rat parvovirus H-1 (ParvOryx) is currently undergoing clinical trials as a treatment for human glioblastoma multiforme [111]. 


\section{Conclusions}

Parvovirus B19 infection may complicate the clinical course of acute leukemia by opportunistic infection which may be acquired exogenously or represent reactivation of latent B19 virus. However, acute B19 infection may precede a diagnosis of acute leukemia by up to 180 days, and in some cases is associated with aplastic crisis, which is already recognized to precede development of acute leukemia in a small percentage of cases. B19 virus is a recognized cause of aplasia, the pathogenesis of which is by direct infection of erythroblasts and B19mediated apoptosis, less frequent infection of other bone marrow cell types, NS1-mediated cytotoxicity of bystander cells, and pro-inflammatory cytokine secretion. In addition, there is evidence of delayed infection with B19 virus in some studies, HLA class I and II associations which match those recognized to predispose to development of acute leukemia, cytokine dysregulation and a particular pattern of DNA methylation of cancer genes which is associated with positivity for serum anti-B19 IgG.

Epidemiological studies suggest that the pathogenesis of acute leukemia involves an unusual response to an ubiquitous virus infection usually acquired during childhood. Other childhood virus infections that have been linked with acute leukemia includehuman herpesvirus 6, cytomegalovirus and Epstein-Barr virus. Human herpes virus 6 was first isolated from the B lymphocytes of patients with lymphoproliferative disorders including one patient with acute lymphoblastic leukemia [112], and was subsequently shown to have oncogenic potential [113] and high viral loads were found in lymphoproliferative diseases [114] However, there is no significant difference in either seroprevalence or nucleic acid prevalence in patients with acute leukemia as compared with controls [115-117]. 
Infectious mononucleosis and positivity in the monospot test have been shown to occur both preceding and at the time of the diagnosis of acute monocytic leukemia [118,119]; 20 cases of infectious mononucleosisassociated acute monocytic leukemia are reviewed in the report by Pedersen et al [119]. Anothersimilar case was shown to be caused by varicella-zoster virus infection [120]. Infectious mononucleosis may be caused by Epstein-Barr virus, cytomegalovirus and varicella-zoster virus. Epstein-Barr virus infection may also masquerade as acute monocytic leukemia [121]. However, despite this interesting association, the nucleic acid prevalences of Epstein-Barr virus, cytomegalovirus and human herpesvirus 6 were found to be $14 \%, 19 \%$, and 9\%, respectively [116], which was taken as evidence against the involvement of these infectious agents in acute leukemia. However, it is difficult to assign pathogenetic significance to the presence of a virus which persists following the acute phase, because the timing of the acute infection and its consequences are unknown at the time of testing.

These authors believe that each case of acute leukemia may be triggered by one of several viruses, including parvovirus B19, and that to identify which virus infection is responsible for a particular case of acute leukemia, it would be necessary to study very large population cohorts, in order to identify the timing of seroconversion to particular viruses occurring contemporaneous with the diagnosis of different types of acute leukemia.

We believe that the current management of parvovirus B19 infections is probably adequate although awareness of the possibility that B19 infection may precede or be contemporaneous with diagnosis of acute leukemia could certainly be improved.

Despite a lot of high quality research in the area of acute childhood leukemia, a particular model of infection with its associated pathogenetic mechanisms has been lacking. Similar to the pathogenesis of other chronic inflammatory and autoimmune diseases, it is most unlikely that B19 virus is the only infectious agent which may trigger an outcome of acute leukemia, but that individual presentations of acute leukemia may 
betriggered by one of a range of viruses. However, the recognition of B19 infection as one particular trigger for the disease in a subset of patients, provides a useful model for further study of this intriguing relationship.

\section{Acknowledgements}

This work was not supported by any funding body. We acknowledge the kind help of Professor Ana Maria Barragan in obtaining published papers.

\section{Statement of author contributions}

Jonathan Kerr conceived the idea for this review, reviewed the literature and drafted the manuscript. Derek Mattey reviewed the literature on HLA associations of both parvovirus B19 and acute leukemia and drafted the HLA sections. Both authors checked the manuscript and corrected errors.

\section{References}

1. Greaves M. Infection, immune responses and the aetiology of childhood leukaemia. Nat Rev Cancer 2006;6:193-203.

2. Kerr JR, Modrow S. (2006). Human parvovirus B19. In The Parvoviruses, pp. 385-416. Edited by JR Kerr, SF Cotmore, ME Bloom, M Linden \& CR Parrish.

3. Barah F, Whiteside S, Batista S, Morris J. Neurological aspects of human parvovirus B19 infection: a systematic review. Rev Med Virol. 2014;24(3):154-68. 
4. Agarwal P, Naseem S, Varma N, Marwaha RK. T-lineage acute lymphoblastic leukemia and parvovirus infection in a child with neurofibromastosis-1. Indian J Pathol Microbiol. 2013;56(4):446-8.

5. Gadage VS, Viswanathan S, Kunal S, Subramanian PG, Gujral S. Parvovirus B19 presenting with persistent pancytopenia in a patient of T-ALL post induction chemotherapy diagnosed on bone marrow examination. Indian J Pathol Microbiol. 2011;54(3):603-5.

6. Magyarosy E, Marosi A, Apjok E. Acute lymphoblastic leukemia in a patient with congenital hemolytic anemia: case report. Orv Hetil. 2001;142(43):2381-2.

7. McNall RY, Head DR, Pui CH, Razzouk BI. Parvovirus B19 infection in a child with acute lymphoblastic leukemia during induction therapy. J Pediatr Hematol Oncol. 2001;23(5):309-11.

8. Heegaard ED, Kerndrup GB, Carlsen NT, Schmiegelow K, Hornsleth AK. Thrombocytopenia caused by Parvovirus B19 infection in a child with acute lymphatic leukemia. Ugeskr Laeger. 1999;161(47):6501-2.

9. Sinclair JP, Croxson MC, Thomas SM, Teague LR, Mauger DC. Chronic parvovirus B19 meningitis in a child with acute lymphocytic leukemia. Pediatr Infect Dis J. 1999;18(4):395-6.

10. Alberti M, Fiori GM, Sanna MA. Parvovirus infection in a child with acute lymphoblastic leukemia. Haematologica. 1999;84(1):85.

11. Mihál V, Dusek J, Hajdúch M, Cohen BJ, Fingerová H, Veselý J. Transient aplastic crisis in a leukemic child caused by parvovirus B19 infection. Pediatr Hematol Oncol. 1996;13(2):173-7.

12. De Renzo A, Azzi A, Zakrzewska K, Cicoira L, Notaro R, Rotoli B. Cytopenia caused by parvovirus in an adult ALL patient. Haematologica. 1994;79(3):259-61.

13. Fisher D, Spencer D, lland H, Brammah S, Cossart Y. Red cell aplasia caused by human parvovirus B19 in acute leukaemia. Aust N Z J Med. 1992;22(3):303-4.

14. Takahashi M, Moriyama Y, Shibata A, Takai K, Sanada M. Anemia caused by parvovirus in an adult patient with acute lymphoblastic leukemia in complete remission. Eur J Haematol. 1991;46(1):47. 
15. Rao SP, Miller ST, Cohen BJ. Severe anemia due to B19 parvovirus infection in children with acute leukemia in remission. Am J Pediatr Hematol Oncol. 1990;12(2):194-7.

16. Kurtzman GJ, Cohen B, Meyers P, Amunullah A, Young NS. Persistent B19 parvovirus infection as a cause of severe chronic anaemia in children with acute lymphocytic leukaemia. Lancet. 1988;2(8621):1159-62.

17. Carstensen H, Ornvold K, Cohen BJ. Human parvovirus B19 infection associated with prolonged erythroblastopenia in a leukemic child. Pediatr Infect Dis J. 1989;8(1):56.

18. Broliden K, Tolfvenstam T, Ohlsson S, Henter JI. Persistent B19 parvovirus infection in pediatric malignancies. Med Pediatr Oncol. 1998;31(2):66-72.

19. Smith TJ, Cullen JW, Peck SD, Brown KE, Young NS. Pancytopenia secondary to parvovirus B19 infection in a child with acute lymphoblastic leukemia, mimicking leukemic relapse. Am J Hematol. $1995 ; 50(3): 226-7$.

20. Matsubara K, Uchida Y, Wada T, et al. Parvovirus B19-associated hemophagocytic lymphohistiocytosis in a child with precursor B-cell acute lymphoblastic leukemia under maintenance chemotherapy. J Pediatr Hematol Oncol. 2011;33(7):565-9.

21. Fattet S, Cassinotti P, Popovic MB. Persistent human parvovirus B19 infection in children under maintenance chemotherapy for acute lymphocytic leukemia. J Pediatr Hematol Oncol. 2004;26(8):497503.

22. Sharma P, Singh T, Mishra D, Gaiha M. Parvovirus B-19 induced acute pure red cell aplasia in patients with chronic lymphocytic leukemia and neurofibromatosis type-1. Hematology. 2006;11(4):257-9.

23. Ergas D, Resnitzky P, Berrebi A. Pure red blood cell aplasia associated with parvovirus B19 infection in large granular lymphocyte leukemia. Blood. 1996 Apr 15;87(8):3523-4.

24. Abla O, Gassas A, Stevens R, Grant R, Abdelhaleem M. bcr-abl-positive T-cell acute lymphoblastic leukemia associated with parvovirus B19 infection. J Pediatr Hematol Oncol. 2006;28(2):98-9. 
25. Yetgin S, Cetin M, Aslan D, Ozyurek E, Anlar B, Uçkan D. Parvovirus B19 infection presenting as pre-Bcell acute lymphoblastic leukemia: a transient and progressive course in two children. J Pediatr Hematol Oncol. 2004;26(10):689-92.

26. Kerr JR, Barah F, Cunniffe VS, et al. Association of acute parvovirus B19 infection with new onset of acute lymphoblastic and myeloblastic leukaemia. J Clin Pathol. 2003;56(11):873-5.

27. Fisgin T, Yarali N, Duru F, Kara A. Parvovirus-B19 infection preceding acute myeloid leukemia with orbital granulocytic sarcoma. Leuk Lymphoma. 2002;43(10):2059-61.

28. Lee SM, Kim DG, Bang D. Persistent erythema infectiosum-like rash as a prodrome of acute lymphocytic leukemia. Pediatr Dermatol. 1994;11(2):156-9.

29. Savasan S, Ozdemir O. Parvovirus B19 infection and acute lymphoblastic leukaemia. Br J Haematol. 2003;120(1):168-9.

30. Petrella T, Bailly F, Mugneret F, et al. Bone marrow necrosis and human parvovirus associated infection preceding an Ph1+ acute lymphoblastic leukemia. Leuk Lymphoma. 1992;8(4-5):415-9.

31. Munthe-Kaas MC, Tierens A, Bechensteen AG, Zeller B. Myeloid Leukemia of Down Syndrome: Relation to Parvovirus B19 Infection and Wilms Tumor Gene (WT1) Expression. J Pediatr Hematol Oncol. 2014 Jan 1. [Epub ahead of print]

32. Heegaard ED, Madsen HO, Schmiegelow K. Transient pancytopenia preceding acute lymphoblastic leukaemia (pre-ALL) precipitated by parvovirus B19. Br J Haematol. 2001;114(4):810-3.

33. Sitar G, Balduini CL, Manenti L, Castello A, Balanzin D, Ascari E. Possible evolution of human parvovirus B19 infection into erythroleukemia. Haematologica. 1999;84(10):957-9.

34. Kondo H, Mori A, Watanabe J, Takada J, Takahashi Y, Iwasaki H. Pure red cell aplasia associated with parvovirus B19 infection in T-large granular lymphocyte leukemia. Leuk Lymphoma. 2001 NovDec;42(6):1439-43. 
35. El-Mahallawy HA, Mansour T, El-Din SE, Hafez M, Abd-el-Latif S. Parvovirus B19 infection as a cause of anemia in pediatric acute lymphoblastic leukemia patients during maintenance chemotherapy. J Pediatr Hematol Oncol. 2004;26(7):403-6.

36. Jitschin R, Peters O, Plentz A, Turowski P, Segerer H, Modrow S. Impact of parvovirus B19 infection on paediatric patients with haematological and/or oncological disorders. Clin Microbiol Infect. 2011;17(9):1336-42.

37. Lindblom A, Heyman M, Gustafsson I, et al. Parvovirus B19 infection in children with acute lymphoblastic leukemia is associated with cytopenia resulting in prolonged interruptions of chemotherapy. Clin Infect Dis. 2008;46(4):528-36. doi: 10.1086/526522.

38. Soliman Oel-S, Abd El-Aal Hegazi Hasan M, El-Ashry R, Zaghloul MH, Kora B. Parvovirus B19 infection in pediatric oncology patients: diagnostic value of clinical and serologic parameters compared with nested PCR. J Pediatr Hematol Oncol. 2009;31(3):173-6.

39. Zaki Mel S, Hassan SA, Seleim T, Lateef RA. Parvovirus B19 infection in children with a variety of hematological disorders. Hematology. 2006;11(4):261-6.

40. Zaki M. Relevance of specific immunoglobulin $\mathrm{M}$ and immunoglobulin $\mathrm{G}$ for parvovirus B19 diagnosis in patients with acute lymphoblastic leukemia receiving chemotherapy: prospective study. Arch Pathol Lab Med. 2007;131(11):1697-9.

41. da Costa AC, Bendit I, de Oliveira AC, Kallas EG, Sabino EC, Sanabani SS. Investigation of human parvovirus B19 occurrence and genetic variability in different leukaemia entities. Clin Microbiol Infect. 2013;19(1):E31-43.

42. Heegaard ED, Jensen L, Hornsleth A, Schmiegelow K. The role of parvovirus B19 infection in childhood acute lymphoblastic leukemia. Pediatr Hematol Oncol. 1999;16(4):329-34. 
43. Heegaard ED, Schmiegelow K. Serologic study on parvovirus B19 infection in childhood acute lymphoblastic leukemia during chemotherapy: clinical and hematologic implications. J Pediatr Hematol Oncol. 2002;24(5):368-73.

44. Ibrahem WN, Hasony HJ, Hassan JG. Human parvovirus B19 in childhood acute lymphoblastic leukaemia in Basrah. J Pak Med Assoc. 2014;64(1):9-12.

45. Kishore J, Sen M, Kumar A, Kumar A. A pilot study on parvovirus B19 infection in paediatric haematological malignancies. Indian J Med Res. 2011;133:407-13.

46. Zaki ME, Ashray RE. Clinical and hematological study for Parvovirus b19 infection in children with acute leukemia. Int J Lab Hematol. 2010;32(2):159-66.

47. Kinlen L. Evidence for an infective cause of childhood leukaemia: comparison of a Scottish new town with nuclear reprocessing sites in Britain. Lancet 1988; 2:1323-7.

48. Greaves MF. Speculations on the cause of childhood acute lymphoblastic leukemia. Leukemia 1988; 2:120- 5 .

49. Urayama KY, Buffler PA, Gallagher ER, Ayoob JM, Ma X. A meta-analysis of the association between day-care attendance and childhood acute lymphoblastic leukaemia. Int J Epidemiol 2010; 39:718-32.

50. McNally RJ, Eden TO. An infectious aetiology for childhood acute leukaemia: a review of the evidence. Br J Haematol 2004; 127:243-63.

51. Little, J. Epidemiology of Childhood Cancer (IARCScientific Publications, Lyon, 1999).

52. Heath, C. W. Jr \& Hasterlik, R. J. Leukemia among children in a suburban community. Am J Med 1963;34:796-812.

53. Alexander, F. E. Space-time clustering of childhood acute lymphoblastic leukaemia: indirect evidence for atransmissible agents. Br J Cancer 1992;65:589-592.

54. Petridou, E. et al. Space-time clustering of childhood leukaemia in Greece: evidence supporting a viralaetiology. Br J Cancer 1996;73: 1278-1283. 
55. Urayama KY, Thompson PD, Taylor M, Trachtenberg EA, Chokkalingam AP. Genetic variation in the extended major histocompatibility complex and susceptibility to childhood acute lymphoblastic leukemia: a review of the evidence. Front Oncol 2013;3:300.

56. Taylor GM, Dearden S, Ravetto P, et al. Genetic susceptibility to childhood common acute lymphoblastic leukaemia is associated with polymorphic peptide-binding pocket profiles inHLA-DPB1*0201. Hum Mol Genet 2002;11:1585-1597.

57. Dorak MT, Lawson T, Machulla HK, Darke C, Mills KI, Burnett AK. Unravelling an HLA-DR association in childhood acute lymphoblastic leukemia. Blood 1999;94:694-700.

58. Wang XJ, Ai XF, Sun HY, et al. Relation of HLA-DRB1*15 with pathogenesis in 162 childhood cases of acute lymphoblastic leukemia. Zhongguo Shi Yan Xue Ye Xue Za Zhi 2009;17(6):1507-10.

59. Khosravi F, Amirzargar A, Sarafnejad A, et al. HLA class II allele and haplotype frequencies in Iranian patients with leukemia. Iran J Allergy Asthma Immunol. 2007;6(3):137-42.

60. Cao HX, Zhao L, Zhou LX. HLA-DRB1 allele polymorphosm associated with susceptibility to leukemia in Hannationality of Gansu. Zhongguo Shi Yan Xue Ye Xue Za Zhi. 2005;13(5):788-92.

61. Ayala FJ, Escalante A, O'Huigin C, Klein J. Molecular genetics of speciation and human origins. Proc Natl Acad Sci U S A. 1994;91(15):6787-94.

62. Cameron ES, Labastide WB, Wilson V, Charles W, Holder Y, Reid HF. Immunophenotypic and HLA studies in childhood acute lymphoblastic leukemia in Trinidad, West Indies. Leukemia. 1990;4(9):615-9.

63. Ozdilli K, Oguz FS, Anak S, Kekik C, Carin M, Gedikoglu G. The frequency of HLA class I and II alleles in Turkish childhood acute leukaemia patients. J Int Med Res. 2010;38(5):1835-44.

64. Klitz W(1), Gragert L, Trachtenberg E. Spectrum of HLA associations: the case of medically refractory pediatric acute lymphoblastic leukemia. Immunogenetics. 2012;64(6):409-19. 
65. Chang JS, Zhou M, Buffler PA, Chokkalingam AP, Metayer C, Wiemels JL. Profound deficit of IL10 at birth in children who develop childhood acute lymphoblastic leukemia. Cancer Epidemiol Biomarkers Prev 2011;20(8):1736-40.

66. Zhang G, Rowe J, Kusel M, Bosco A, McKenna K, de Klerk N, et al. Interleukin-10 / interleukin-5 responses at birth predict risk for respiratory infections in children with atopic family history. Am J Respir Crit Care Med 2009;179(3):205-211.

67. Wiemels J. Perspectives on the causes of childhood leukemia. Chem Biol Interact. 2012 5;196(3):59-67

68. Breatnach F, Chessells JM, Greaves MF. The aplastic presentation of childhood leukaemia: a feature of common-ALL. Br J Haematol 1981;49:387-393.

69. Hasle H, Heim S, Schroeder H, Schmiegelow K, Ostergaard E, Kerndrup G. Transient pancytopenia preceding acute lymphoblastic leukemia (pre-ALL). Leukemia1995;9:605-608.

70. Liang R, Cheng G, Wat MS, Ha SY, Chan LC. Childhood acute lymphoblastic leukaemia presenting with relapsing hypoplastic anaemia: progression of the same abnormal clone. Br J Haematol 1993;83:340342.

71. Ishikawa K, Seriu T, Watanabe A, et al.Detection of neoplastic clone in the hypoplastic and recovery phases preceding acute lymphoblastic leukemia by in vitro amplification of rearranged T-cell receptor delta chain gene. J Pediatr Hematol Oncol 1995;17:270-275.

72. Moffatt S, Yaegashi N, Tada K, Tanaka N, Sugamura K.Human parvovirus B19 nonstructural protein (NS1)induces apoptosis in erythroid lineage cells. J Virol1998;72:3018-28.

73. Young NS, Mortimer PP,Moore JG, Humphries RK. Characterisationof a virus that causes transient aplastic crisis. JClin Invest 1984;73:224-30.

74. Anderson MJ. Human parvoviruses. In: Zuckerman AJ,Banatvala JE, Pattison JR, eds. Principles and practice ofclinical virology. New York: Wiley, 1990:561-72. 
75. Anderson MJ, Higging PG, Davis LR, Willman JS, JonesSE, Kidd IM, et al. Experimental parvovirus infection inhumans. J Infect Dis 1985;152:257-65.

76. Potter CG, Potter AC,Hatton CSR, Chapel HM, AndersonMJ, Pattison JR, et al. Variation of erythroid and myeloidprecursors in the marrow and peripheral blood of volunteersubjects infected with human parvovirus B19. J Clin Invest1987;79:1486-92.

77. Schwarz TF,Wiersbitzky S, Pambor M. Case report: detectionof parvovirus B19 in a skin biopsy of a patient witherythema infectiosum. J Med Virol 1994;43:171-4.

78. Kerr JR, Mattey DL, Thomson W, Poulton KV, Ollier WE. Association of symptomatic acute human parvovirus B19 infection with human leukocyte antigen class I and II alleles. J Infect Dis 2002;186(4):447-52.

79. Kinney JS, Anderson LJ, Farrar J, Strikas RA, Kumar ML,Kliegman RM, et al. Risk of adverse outcomes of pregnancyafter human parvovirus B19 infection. J Infect Dis1988;157:663-7.

80. Morey AL, Ferguson DJ, Fleming KA. Ultrastructural features of fetal erythroid precursors infected with parvovirus B19 in vitro: evidence of cell death by apoptosis. J Pathol 1993;169:213-20.

81. Moffatt S, Tanaka N, Tada K, Nose M, Nakamura M, Muraoka O, et al. A cytotoxic nonstructural protein, NS1, of human parvovirus B19 induces activation of interleukin-6 gene expression. J Virol 1996;70:8485-91.

82. Wagner AD, Goronzy JJ, Matteson EL, Weyand CM.Systemic monocyte and T cell activation in a patient withhuman parvovirus B19 infection. Mayo Clin Proc 1995;70:261-5.

83. Naides SJ, Howard EJ, Swack NS, True CA, Stapleton JT.Parvovirus B19 infection in human immunodeficiencyvirus type 1-infected persons failing or intolerant tozidovudine therapy. J Infect Dis 1993;168:101-5. 
84. Lunardi C, Tiso M, Borgato L, Nanni L, Millo R, De SandreG, et al. Chronic parvovirus B19 infection induces theproduction of anti-virus antibodies with autoantigen bindingproperties. Eur J Immunol 1998;28:936-48.

85. Loizou S, Cazabon JK, Walport MJ, Tait D, So AK. Similarities of specificity and cofactor dependence in serum antiphospholipid antibodies from patients with human parvovirus B19 infection and from those with systemic lupus erythematosus. Arthritis Rheum 1997;40(1):103-8.

86. Vuorinen T, Lammintausta K, Kotilainen P, Nikkari S. Presence of parvovirus B19 DNA in chronic urticaric and healthy human skin. J Clin Virol 2002;25(2):217-21.

87. Barah F, Vallely PJ, Chiswick ML, Cleator GM, Kerr JR. Association of human parvovirus B19 infection with acute meningoencephalitis. Lancet 2001;358:729-30.

88. Barah F, Vallely PJ, Cleator GM, Kerr JR. Neurological manifestations of human parvovirus B19 infection. Reviews in Medical Virology 2003;13:185-99.

89. Kerr JR, Barah F, Chiswick ML, McDonnell GV, Smith J, Chapman MD, Bingham JB, et al. Evidence for the role of demyelination, HLA-DR alleles, and cytokines in the pathogenesis of parvovirus B19 meningoencephalitis and its sequelae. J Neurol Neurosurg Psychiatry. 2002;73(6):739-46.

90. Andres E, Grunenberger F, Schlienger JL, Imler M. Cutaneousvasculitis disclosing parvovirus B19 infection. AnnMed Interne (Paris) 1997;148:107-8.

91. Corman LC, Dolson DJ. Polyarteritis nodosa and parvovirusB19 infection. Lancet 1992;339:491.

92. Corman LC, Staud R. Association of Wegener's granulomatosiswith parvovirus B19 infection: comment on theconcise communication by Nikkari et al. Arthritis Rheum1995;38:1174-5.

93. Finkel TH, Torok TJ, Ferguson PJ, Durigon EL, Zaki SR,Leung DY, et al. Chronic parvovirus B19 infection and systemicnecrotising vasculitis: opportunistic infection oraetiological agent? Lancet 1994;343:12558. 
94. Nikkari S, Roivainen A, Hannonen P, Mottonen T, Luukkainen R, Yli-Jama T, et al. Persistence of parvovirusB19 in synovial fluid and bone marrow. Ann Rheum Dis1995;54:597-600.

95. Chakravarty K, Merry P. Systemic vasculitis and atypicalinfections: report of two cases. Postgrad Med J 1999;75:544-6.

96. Martinelli C, Azzi A, Buffini G, Comin CE, Leoncini F.Cutaneous vasculitis due to human parvovirus B19 in anHIV-infected patient: report of a case. AIDS 1997;11:1891-3.

97. Gabriel SE, Espy M, Erdman DD, Bjornsson J, Smith TF,Hunder GG. The role of parvovirus B19 in the pathogenesisof giant cell arteritis: a preliminary evaluation. ArthritisRheum 1999;42:1255-8.

98. Osaki M, Matsubara K, Iwasaki T, Kurata T, Nigami H,Harigaya H, et al. Severe aplastic anemia associated withhuman parvovirus B19 infection in a patient withoutunderlying disease. Ann Hematol 1999;78:83-6.

99. Pont J, Puchhammer-Stockl E, Chott A, Popow-Kraupp T, Kienzer H, Postner G, et al. Recurrent granulocytic aplasiaas clinical presentation of a persistent parvovirus B19infection. $\mathrm{Br} \mathrm{J}$ Haematol1992;80:160-5.

100. Vasconcelos GM, Kang M, Pombo-de-Oliveira MS, Schiffman JD, Lorey F, Buffler P, et al. Adenovirus detection in Guthrie cards from paediatric leukaemia cases and controls. Br J Cancer 2008; 99:1668-72.

101. Kerr JR, Barah F, Mattey DL, Laing I, Hopkins SJ, Hutchinson IV, Tyrrell DA. Circulating tumour necrosis factor-alpha and interferon-gamma are detectable during acute and convalescent parvovirus B19 infection and are associated with prolonged and chronic fatigue. J Gen Virol. 2001;82( 12):3011-9. 102. Kerr JR, Cunniffe VS, Kelleher P, Coats AJ, Mattey DL. Circulating cytokines and chemokines in acute symptomatic parvovirus B19 infection: negative association between levels of pro-inflammatory cytokines and development of B19-associated arthritis. J Med Virol. 2004;74(1):147-55. 
103. Kerr JR, McCoy M, Burke B, Mattey DL, Pravica V, Hutchinson IV. Cytokine gene polymorphisms associated with symptomatic parvovirus B19 infection. J Clin Pathol. 2003;56(10):725-7.

104. Söderlund-Venermo M, Hokynar K, Nieminen J, Rautakorpi H, Hedman K. Persistence of human parvovirus B19 in human tissues. Pathol Biol (Paris). 2002;50(5):307-16.

105. Kerr JR, Boschetti N. Short regions of sequence identity between the genomes of human and rodent parvoviruses and their respective hosts occur within host genes for the cytoskeleton, cell adhesion and Wnt signalling. J Gen Virol 2006;87( 12):3567-75.

106. Martin D, Gutkind JS. Human tumor-associated viruses and new insights into the molecular mechanisms of cancer. Oncogene. 2008;27 Suppl 2:S31-42.

107. Dalianis T, Ramqvist T, Andreasson K, Kean JM, Garcea RL. KI, WU and Merkel cell polyomaviruses: a new era for human polyomavirus research. Semin Cancer Biol. 2009 Aug;19(4):2705.

108. Fu Y, Ishii KK, Munakata Y, Saitoh T, Kaku M, Sasaki T. Regulation of tumor necrosis factor alpha promoter by human parvovirus B19 NS1 through activation of AP-1 and AP-2. J Virol. 2002 Jun;76(11):5395-403.

109. Adamson-Small LA, Ignatovich IV, Laemmerhirt MG, Hobbs JA. Persistent parvovirus B19 infection in non-erythroid tissues: possible role in the inflammatory and disease process. Virus Res. 2014 Sep 22;190:8-16.

110. Rommelaere J, Geletneky K, Angelova AL, Daeffler L, Dinsart C, Kiprianova I, et al. Oncolytic parvoviruses as cancer therapeutics. Cytokine Growth Factor Rev. 2010 Apr-Jun;21(2-3):185-95.

111. Geletneky K, Huesing J, Rommelaere J, Schlehofer JR, Leuchs B, Dahm M, et al. Phase I/Ila study of intratumoral/intracerebral or intravenous/intracerebral administration of Parvovirus $\mathrm{H}-1$ (ParvOryx) in patients with progressive primary or recurrent glioblastoma multiforme: ParvOryx01 protocol. BMC Cancer 2012;12:99. 
112. Salahuddin SZ, Ablashi DV, Markham PD, Josephs SF, Sturzenegger S, Kaplan M, et al. Isolation of a new virus, HBLV, in patients with lymphoproliferative disorders. Science. 1986;234(4776):596-601.

113. Razzaque A. Oncogenic potential of human herpesvirus-6 DNA. Oncogene 1990;5:1365-1370.

114. Ohyashiki JH, Abe K,Ojima T, Wang P, Zhou CF, Suzuki A, Ohyashiki K, Yamamoto K.

Quantification of human herpesvirus 6 in

healthyvolunteersandpatientswithlymphoproliferativedisorders by PCR-ELISA. Leuk Res 1999;23:625630.

115. Seror E, Coquerel B, Gautheret-Dejean A, Ballerini P, Landman-Parker J, Leverger G, et al. Quantitation of Human herpes virus 6 genome in children with acute lymphoblastic leukemia. J Med Virol. 2008;80(4):689-93.

116. Morales-Sánchez A, Pompa-Mera EN, Fajardo-Gutiérrez A, Alvarez-Rodríguez FJ, BekkerMéndez VC, Flores-Chapa Jde D, et al. EBV, HCMV, HHV6, and HHV7 screening in bone marrow samples from children with acute lymphoblastic leukemia. Biomed Res Int. 2014;2014:548097.

117. Levine PH, Ablashi DV, Saxinger WC, Connelly RR. Antibodies to human herpes virus-6 in patients with acute lymphocytic leukemia. Leukemia. 1992;6(11):1229-31.

118. Miale TD, Barbosa JL, Dellinger CT, Wolfson SL. Positive monospot tests preceding the diagnosis of acute monocytic leukemia in two adolescents. Med Pediatr Oncol. 1978;4(2):111-4. PubMed PMID: 275531.

119. Pedersen PR, Gerber P, Sweeney G, Blom J. Infectious mononucleosis preceding acute myelomonocytic leukemia. Am J Med Sci. 1975 Jan-Feb;269(1):131-5.

120. Tamayose K, Sugimoto K, Ando M, Oshimi K. Mononucleosis syndrome and acute monocytic leukemia. Eur J Haematol. 2002;68(4):236-8. 
121. Chhabra P, Law AD, Sharma U, Suri V, Sachdeva MS, Kumari S, et al. Epstein-barr virus infection masquerading as acute leukemia: a report of two cases and review of literature. Indian J Hematol Blood Transfus. 2014;30(1):26-8. 


\section{Figure 1 Legend}

A model of the time course and important events in the pathogenesis of parvovirus B19-associated childhood acute lymphoblastic leukemia (ALL).

Initiating mutations occur at a frequency of approximately $1 \%$ of normal live births, and among these a second activating mutation occurring after birth in the same cell that harbors the initiating mutation is rare, occurring only in those with an increased potential to react vigorously to early life infections, who have also had a reduced level of exposure to early life infections. According to this model, infection occurs and hematopoiesis is suppressed, allowing the selective outgrowth of pre-leukemic clones, one of which acquires the activating mutation, and with rapid proliferation, develops into ALL. In this model, the infection is by parvovirus B19, which is known to cause reticulocyte arrest and aplastic anemia, and in some individuals, to elicit a vigorous immune response with the potential to further suppress hematopoiesis by the action of cytokines. This figure was adapted from Figure 2 of the review of Greaves [1] and Figure 3 of the review of Wiemels [67]. 
Table 1. Case reports of B19 infection in acute leukemia during chemotherapy

\begin{tabular}{|c|c|c|c|c|c|c|c|c|c|c|c|c|c|c|c|}
\hline $\begin{array}{l}\text { Case } \\
\text { No. }\end{array}$ & $\begin{array}{l}\text { Leukemia } \\
\text { type* }\end{array}$ & $\begin{array}{l}\text { Past } \\
\text { Medical } \\
\text { History** }\end{array}$ & Age & Sex & $\begin{array}{l}\text { Bone marrow at } \\
\text { presentation }\end{array}$ & $\begin{array}{l}\text { Leukemia } \\
\text { Treatment } \\
\text { status at time } \\
\text { of B19 infection }\end{array}$ & $\begin{array}{l}\text { Interval } \\
\text { between } \\
\text { leukemia } \\
\text { diagnosis } \\
\text { and B19 } \\
\text { onset }\end{array}$ & $\begin{array}{l}\text { B19 symptoms, } \\
\text { signs \& markers }{ }^{\prime}\end{array}$ & $\begin{array}{l}\text { Hemoglobin } \\
\text { at time of } \\
\text { B19 infection } \\
(\mathrm{g} / \mathrm{dL})\end{array}$ & $\begin{array}{l}\text { Platelets } \\
10^{9} / \mathrm{L}\end{array}$ & $\begin{array}{l}\text { White } \\
\text { Blood } \\
\text { Count } \\
10^{9} / \mathrm{L}\end{array}$ & $\begin{array}{l}\text { Neutro } \\
\text { phils } \\
10^{9} / \mathrm{L}\end{array}$ & $\begin{array}{l}\text { Treatm } \\
\text { ent for } \\
\text { B19 } \\
\text { infectio } \\
\text { n§ }\end{array}$ & $\begin{array}{l}\text { Hemoglobi } \\
\mathrm{n} \text { post-B19 } \\
\text { infection } \\
(\mathrm{g} / \mathrm{dL})\end{array}$ & $\begin{array}{l}\text { Reference } \\
\text { number }\end{array}$ \\
\hline
\end{tabular}

\begin{tabular}{|c|c|c|c|c|c|c|c|c|c|c|c|c|c|c|}
\hline 1 & ALL & NF-1 & 12 & M & $\begin{array}{l}\text { Hypercellular with } \\
\text { immature cells }\end{array}$ & Induction & $14 d$ & $\begin{array}{l}\text { BM - GPNB, } \\
\text { erythroblastopenia }\end{array}$ & 10.8 & 2.44 & 6.0 & $?$ & - & \\
\hline 2 & ALL & & 38 & M & $\begin{array}{l}\text { Hypocellular, } \\
\text { erythroblastopenia }\end{array}$ & Induction & $30 \mathrm{~d}$ & $\begin{array}{l}\text { BM - GPNB, } \\
\text { erythroblastopenia } \\
\text { IgM+ }\end{array}$ & 9.6 & 900 & 0.648 & $28.2 \%$ & IVIG & 12 \\
\hline 3 & ALL & $\begin{array}{l}\text { Spherocy } \\
\text { tosis }\end{array}$ & 13 & $\mathrm{~F}$ & Not stated & Maintenance & $\begin{array}{l}\text { Not } \\
\text { stated }\end{array}$ & Aplastic crisis & $?$ & $?$ & ? & $?$ & $?$ & $?$ \\
\hline 4 & ALL & & 6 & $\mathrm{~F}$ & Lymphoblasts & Induction & $36 d$ & $\begin{array}{l}\text { D46 BM - GPNB, } \\
\text { erythroblastopenia } \\
\text { DNA+ }\end{array}$ & 8.0 & 5.0 & ? & 0 & $\begin{array}{l}\text { RCT, } \\
\text { IVIG }\end{array}$ & 9.7 \\
\hline 5 & ALL & & 3 & M & Not stated & Maintenance & $2 y$ & DNA+ & $?$ & low & $?$ & $?$ & $?$ & $?$ \\
\hline 6 & ALL & & 2.5 & $\mathrm{~F}$ & Pancytopenia & Maintenance & $20 \mathrm{~m}$ & $\begin{array}{l}\text { DNA+, IgM+, IgG+ } \\
\text { CSF - DNA+ }\end{array}$ & 10.0 & 92 & 1.6 & $55 \%$ & - & ? \\
\hline 7 & ALL & & 6 & M & Not stated & Maintenance & $\begin{array}{l}\text { Not } \\
\text { stated }\end{array}$ & $\begin{array}{l}\text { BM - GPNB, } \\
\text { erythroblastopenia }\end{array}$ & 7.0 & low & $?$ & $?$ & IVIG & Normal \\
\hline 8 & ALL & & 8 & $\mathrm{~F}$ & Not stated & Maintenance & $\begin{array}{l}\text { Not } \\
\text { stated }\end{array}$ & IgM+, DNA+ & $<5.0$ & low & low & ? & $\begin{array}{l}\text { RCT, } \\
\text { IVIG }\end{array}$ & Normal \\
\hline 9 & ALL & & 22 & $\mathrm{~F}$ & Not stated & Maintenance & $6 y$ & $\begin{array}{l}\text { Erythroblastopenia } \\
\text { IgG+, DNA+ }\end{array}$ & 8.0 & $?$ & $?$ & ? & $\begin{array}{l}\text { RCT, } \\
\text { IVIG }\end{array}$ & 14.0 \\
\hline 10 & ALL & & 17 & M & $90 \%$ lymphoblasts & $\begin{array}{l}\text { Between } \\
\text { chemotherapy }\end{array}$ & $8 \mathrm{~m}$ & $\begin{array}{l}\text { BM - GPNB, } \\
\text { erythroblastopenia } \\
\text { IgM+, IgG+, DNA+ }\end{array}$ & 9.6 & 64 & normal & normal & RCT & Normal \\
\hline 11 & ALL & FAB:L2 & 42 & $\mathrm{~F}$ & Not stated & Maintenance & & $\begin{array}{l}\text { reticulocytopenia, } \\
\text { BM - GPNB, } \\
\text { erythroblastopenia. } \\
\text { B19 antigen + }\end{array}$ & 6.4 & 69 & $?$ & $?$ & none & Normal \\
\hline 12 & ALL & & 4 & M & Not stated & Maintenance & $3 y 7 m$ & $\begin{array}{l}\text { B19 - GPNB, } \\
\text { Erythroblastopenia } \\
\text { B19 markers -ve } \\
\text { Later - IgM+, IgG+ }\end{array}$ & 5.8 & 408 & 6.4 & $40 \%$ & RCT & 11.0 \\
\hline 13 & ALL & & ? & $?$ & Not stated & Maintenance & $6 \mathrm{~m}$ & $\begin{array}{l}\text { Erythroblastopenia } \\
\text { DNA+, EM+ }\end{array}$ & 4.7 & 656 & 2.1 & ? & RCT & 11.5 \\
\hline 14 & ALL & & 9 & M & Lymphoblasts & Maintenance & $22 \mathrm{~m}$ & $\begin{array}{l}\text { BM - erythroid } \\
\text { hypoplasia, DNA+ }\end{array}$ & 8.8 & 58 & 25.1 & ? & $\begin{array}{l}\text { RCT, } \\
\text { IVIG }\end{array}$ & $?$ \\
\hline 15 & ALL & & 10 & M & Not stated & Maintenance & $1 y$ & $\begin{array}{l}\text { BM - GPNB, } \\
\text { erythroid } \\
\text { hypoplasia, IgM+, } \\
\text { IgG+, DNA+ }\end{array}$ & 6.5 & 119 & 1 & ? & $\begin{array}{l}\text { Chemo } \\
\text { stoppe } \\
\text { d }\end{array}$ & Normal \\
\hline 16 & ALL & & 10 & $\mathrm{~F}$ & Not stated & Maintenance & $15 \mathrm{~m}$ & Fever, rash, DNA+, & 7.4 & 76 & 0.3 & 0 & Chemo & ? \\
\hline
\end{tabular}


Maintenance $\quad 18 \mathrm{~m}$

Conjunctivitis,

lethargy, DNA+,

$\lg \mathrm{M}+$

erythroid

hypoplasia, IgM+,

DNA+

BM - GPNB,

erythroid

hypoplasia, DNA+,

$\operatorname{lgM}+{ }^{+\dagger}$

20 Pre-B ALL

$1 \quad$ M Immature blasts

Maintenance, in $14 \mathrm{~m}$ complete

remission

21 Pre-B ALL

5 M Not stated

Maintenance

$26 m$

BM-GPNB,

erythroid

hypoplasia, DNA +†

$\operatorname{lgM}+$, IgG+, DNA+

Acute hepatitis $6 \mathrm{~m}$

earlier, DNA

detected at $10^{2}$

BM-GPNB,

erythroid

Maintenance $\quad 23 \mathrm{~m}$

$16.5 \mathrm{~m}$

Maintenance

$16 \mathrm{~m}$

Pre-B ALL

Not stated

Pre-B ALL

Not stated

AML-M6b

CML bcr- 12

Not stated

LGLL $a b l+$

65

Not stated

Maintenance

$22.75 \mathrm{~m}$

Splenectomy

$>1 y$

$14 y$

DNA++

DNA+ +†

Fever, rash, DNA+

BM - 80\% GPNB,

death in 1 week

$\mathrm{BM}$ - diffuse

lymphocytosis,

reduced erythroid

precursors. IgM+

IgG-

BM - diffuse

lymphocytosis, rare

erythroid

precursors. IgM+

IgG-

BM -

lymphocytosis,

decrease in

erythroid

precursors. IgM+

IgG-

\begin{tabular}{|c|c|c|c|c|c|}
\hline & & & $\begin{array}{l}\text { stoppe } \\
\text { d }\end{array}$ & & \\
\hline normal & normal & normal & $\begin{array}{l}\text { Chemo } \\
\text { stoppe } \\
\text { d }\end{array}$ & $?$ & 18 \\
\hline 89 & 0.8 & 0.448 & - & Resolution & 19 \\
\hline 98 & 1.2 & $11.5 \%$ & $\begin{array}{l}\text { IVIG, } \\
\text { Steroid }\end{array}$ & Resolution & 20 \\
\hline 18 & 13.4 & $?$ & RCT & $\begin{array}{l}\text { Resolution } \\
\text { at } 1 \mathrm{yr}\end{array}$ & 16 \\
\hline 19 & 0.5 & 0 & $\begin{array}{l}\text { RCT, } \\
\text { IVIG }\end{array}$ & 13.2 & 21 \\
\hline 88 & 1.2 & 0.720 & $\begin{array}{l}\text { RCT, } \\
\text { IVIG }\end{array}$ & 12.0 & 21 \\
\hline 38 & 1.1 & 0.451 & IVIG & 8.8 & 21 \\
\hline 54 & 1.4 & 0.308 & IVIG & 12.6 & 21 \\
\hline 235 & 6.5 & 0.986 & IVIG & 12.3 & 21 \\
\hline 20 & 55 & $?$ & - & - & 22 \\
\hline$?$ & $?$ & $?$ & $\begin{array}{l}\text { IVIG, } \\
\text { RCT, } \\
\text { steroid }\end{array}$ & $\begin{array}{l}\text { Transfusion } \\
\text { dependent }\end{array}$ & 23 \\
\hline ? & $?$ & $?$ & $\begin{array}{l}\text { IVIG, } \\
\text { RCT }\end{array}$ & Resolution & 23 \\
\hline normal & normal & low & RCT & Resolution & 23 \\
\hline
\end{tabular}

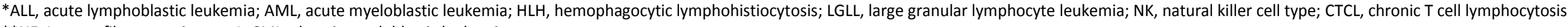

**NF-1, neurofibromatosis type-1, CML, chronic myeloblastic leukemia.

†BM, bone marrow; GPNB, giant pronormoblasts.

trcontact with erythema infectiosum

IVIG, intravenous immunoglobulin; RCT, red cell transfusion. 
Table 2. Case reports ofB19 infection in acute leukemia prior to or at the time of diagnosis

\begin{tabular}{|c|c|c|c|c|c|c|c|c|c|c|c|c|c|c|c|c|}
\hline $\begin{array}{l}\text { Case } \\
\text { No. }\end{array}$ & $\begin{array}{c}\text { B19- } \\
\text { associated } \\
\text { prodrome }\end{array}$ & $\begin{array}{l}\text { Leukemia } \\
\text { type* }\end{array}$ & Age & Sex & $\begin{array}{c}\text { Clinical } \\
\text { presentation** }\end{array}$ & $\begin{array}{l}\text { B19 markers } \\
\text { at } \\
\text { presentation }\end{array}$ & $\begin{array}{l}\text { Bone marrow } \\
\text { at acute B19 } \\
\text { infection' }\end{array}$ & $\begin{array}{l}\text { Hemoglo } \\
\text { bin at } \\
\text { presenta } \\
\text { tion } \\
\text { (g/dL) }\end{array}$ & $\begin{array}{l}\text { Platele } \\
\text { ts } \\
10^{9} / \mathrm{L}\end{array}$ & $\begin{array}{l}\text { White } \\
\text { Blood } \\
\text { Count } \\
10^{9} / \mathrm{L}\end{array}$ & $\begin{array}{c}\text { Neutrophi } \\
\text { Is } \\
10^{9} / \mathrm{L}\end{array}$ & $\begin{array}{c}\text { Interval } \\
\text { between B19 } \\
\text { infection and } \\
\text { leukemia } \\
\text { onset (days) }\end{array}$ & $\begin{array}{l}\text { Rx for } \\
\text { B19+† }\end{array}$ & Outcome & Other & $\begin{array}{l}\text { Referenc } \\
\text { e number }\end{array}$ \\
\hline 1 & - & $\begin{array}{c}\text { T-ALL } \\
\text { Bcr-abl+ }\end{array}$ & $16 y$ & $M$ & $\begin{array}{l}\text { Septic shock, } \\
\text { pancytopenia }\end{array}$ & DNA + , IgG+ & & 8.2 & 90 & 2.5 & 0 & 0 & - & $\begin{array}{l}\text { Death due to } \\
\text { idiopathic } \\
\text { pneumonia } \\
\text { syndrome }\end{array}$ & & 24 \\
\hline 2 & - & ALL & $4 y$ & $\mathrm{~F}$ & $\begin{array}{l}\text { Petechiae, Hep- } \\
\text { spl }\end{array}$ & DNA + , IgG+ & & 11.2 & 18 & 15 & Not stated & 0 & $\begin{array}{l}\text { Plat tx } \\
\text { RCT }\end{array}$ & $\begin{array}{c}\text { Difficult, } \\
\text { delayed } \\
\text { chemotherapy }\end{array}$ & $\begin{array}{c}\text { Down } \\
\text { Syndrome }\end{array}$ & 18 \\
\hline 3 & - & ALL & $16 \mathrm{~m}$ & $\mathrm{~F}$ & $\begin{array}{l}\text { Ataxia, } \\
\text { nystagmus, } \\
\text { tremor, } \\
\text { weakness }\end{array}$ & $\lg \mathrm{M}_{+}$ & GPNB & 12.2 & 345 & 13 & $25 \%$ & 0 & IVIG & $\begin{array}{l}\text { gradual } \\
\text { recovery }\end{array}$ & & 25 \\
\hline 4 & - & Pre-B ALL & $13 m$ & $F$ & $\begin{array}{l}\text { Fever, orbital } \\
\text { edema }\end{array}$ & $\lg M+$ & & 10.0 & 417 & 2.8 & $19 \%$ & 0 & - & Not stated & & 25 \\
\hline 5 & - & $\begin{array}{c}\text { Common } \\
\text { ALL }\end{array}$ & $\begin{array}{l}7 y \\
2 m\end{array}$ & $F$ & $\begin{array}{l}\text { Pallor, scalp } \\
\text { swelling }\end{array}$ & DNA+, IgG+ & $\begin{array}{l}\text { Lymphoblasts } \\
\text { \& Erythroid } \\
\text { hypoplasia }\end{array}$ & 5.4 & 130 & 2.3 & - & 1 & RCT & $\begin{array}{c}\text { Remission } \\
\text { post- } \\
\text { chemotherapy }\end{array}$ & & 26 \\
\hline 6 & - & AML M7 & $\begin{array}{l}1 y \\
6 m\end{array}$ & $F$ & $\begin{array}{c}\text { Pallor, rash, } \\
\text { pancytopenia, L, } \\
\text { leg pain, hep-spl }\end{array}$ & $\begin{array}{c}\text { DNA+, IgM+, } \\
\text { IgG+ }\end{array}$ & $\begin{array}{l}\text { Lymphoblasts } \\
\text { \& Erythroid } \\
\text { hypoplasia }\end{array}$ & 4.2 & 58 & 1.1 & - & 1 & $\begin{array}{l}\text { Plat tx, } \\
\text { RCT }\end{array}$ & $\begin{array}{l}\text { Death due to } \\
\text { relapse }\end{array}$ & & 26 \\
\hline 7 & - & $\begin{array}{l}\text { Common } \\
\text { ALL }\end{array}$ & $\begin{array}{c}6 y \\
11 \mathrm{~m}\end{array}$ & $\mathrm{~F}$ & $\begin{array}{l}\text { Polyarthralgia, } \\
\text { fever, rash, L, } \\
\text { hep-spl, pallor }\end{array}$ & $\begin{array}{l}\text { DNA+, IgM+, } \\
\text { IgG+ }\end{array}$ & $\begin{array}{l}\text { Lymphoblasts } \\
\& \text { Erythroid } \\
\text { hypoplasia }\end{array}$ & 3.0 & 11 & 17 & - & 3 & $\begin{array}{l}\text { Plat tx, } \\
\text { RCT }\end{array}$ & $\begin{array}{c}\text { Remission } \\
\text { post- } \\
\text { chemotherapy }\end{array}$ & & 26 \\
\hline 8 & - & $\begin{array}{l}\text { Null cell } \\
\text { ALL }\end{array}$ & $\begin{array}{l}2 y \\
3 m\end{array}$ & $M$ & $\begin{array}{l}\text { Cough, fever, } \\
\text { pallor, } L \text {, hep-spl }\end{array}$ & DNA + , IgG+ & $\begin{array}{l}\text { Lymphoblasts } \\
\& \text { Erythroid } \\
\text { hypoplasia }\end{array}$ & 5.5 & 411 & 60 & low & 3 & RCT & $\begin{array}{l}\text { Death during } \\
\text { chemo, bac } \\
\text { sepsis }\end{array}$ & & 26 \\
\hline 9 & $\begin{array}{l}\text { Aplastic } \\
\text { crisis }\end{array}$ & AML & $18 \mathrm{~m}$ & $M$ & Fever, pallor & IgM+ & $\begin{array}{c}\text { Pancytopenia, } \\
\text { GPNB }\end{array}$ & 3.6 & 199 & 3.2 & $18 \%$ & 14 & RCT & $\begin{array}{c}\text { Remission } \\
\text { post- } \\
\text { chemotherapy }\end{array}$ & $\begin{array}{c}\text { Orbital } \\
\text { sarcoma }\end{array}$ & 27 \\
\hline 10 & $\begin{array}{l}\text { Aplastic } \\
\text { crisis }\end{array}$ & ALL & $7 y$ & $M$ & $\begin{array}{c}\text { Fever, arthralgia, } \\
\text { rash, hep-spl, L }\end{array}$ & - & $\begin{array}{l}\text { Lymphoblasts } \\
\text { \& Erythroid } \\
\text { hypoplasia }\end{array}$ & 7.3 & 238 & 12.5 & $43 \%$ & 40 & - & $\begin{array}{l}\text { Chemo with } \\
\text { remission }\end{array}$ & $\begin{array}{c}\text { Sezary } \\
\text { cells and } \\
\text { monocyte } \\
\text { s in skin } \\
\text { biopsy }\end{array}$ & 28 \\
\hline 11 & $\begin{array}{l}\text { Aplastic } \\
\text { crisis }\end{array}$ & ALL & $1 y$ & $\mathrm{~F}$ & $\begin{array}{c}\text { Fever, L, pallor, } \\
\text { Hep-spl, }\end{array}$ & $\operatorname{lgM}+, \lg G+$ & $\begin{array}{l}\text { Erythroid } \\
\text { hypoplasia, } \\
\text { myeloblasts }\end{array}$ & 2.6 & 243 & 3.6 & 0.25 & 63 & - & Not stated & & 29 \\
\hline 12 & $\begin{array}{l}\text { Aplastic } \\
\text { crisis }\end{array}$ & $\begin{array}{c}\text { ALL-type } 1 \\
\text { Ph1+ }\end{array}$ & $23 y$ & $\mathrm{~F}$ & Back pain, fever & $\lg \mathrm{I}+$ & necrosis & 8.0 & 3 & 2.4 & $48 \%$ & 63 & - & $\begin{array}{l}\text { Chemo with } \\
\text { remission }\end{array}$ & $\begin{array}{l}\text { Considere } \\
d \text { for BMT }\end{array}$ & 30 \\
\hline 13 & $\begin{array}{l}\text { Aplastic } \\
\text { crisis }\end{array}$ & AML & $13 m$ & $M$ & Not stated & $\begin{array}{l}\text { DNA+, IgM+, } \\
\operatorname{lgG}+\end{array}$ & $\begin{array}{l}\text { Pancytopenia, } \\
\text { megakaryocyti } \\
\text { c blasts }\end{array}$ & 3.1 & $<10$ & 3.3 & 0.7 & 75 & - & $\begin{array}{c}\text { Recovery at } \\
47 \text { weeks, post- } \\
\text { chemo }\end{array}$ & Downs & 31 \\
\hline
\end{tabular}




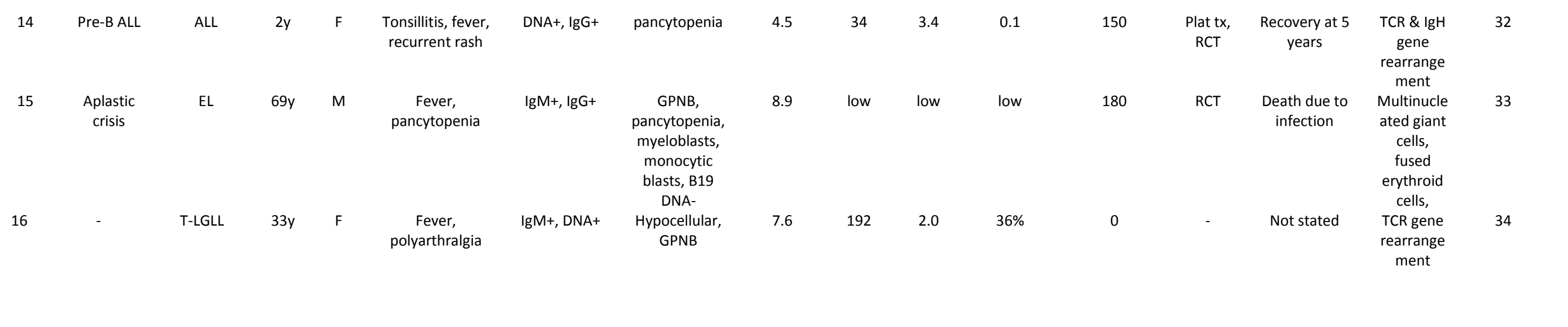

*ALL, acute lymphoblastic leukemia; AML, acute myeloblastic leukemia; Ph1, Philadelphia chromosome; EL, erythroleukemia, T-LGLL, T cell large granular lymphocyte leukemia.

**Hep-spl, hepatosplenomegaly; L, lymphadenopathy.

$\mathrm{GPNB}$, giant pronormoblasts.

†tplat tx, platelet transfusion; RCT, red cell transfusion; IVIG, intravenous immunoglobulin; BMT, bone marrow transplant; TCR, T cell receptor.

Mother also had these B19 markers 
Parvovirus B19 Markers

No. subjects (percentage)

\section{Clinical category}

(Number of subjects)

$\begin{array}{cccccc}\text { Bone } & \text { Serum } & \text { Serum anti- } & \text { Serum anti- } & \text { Country of } & \text { Reference } \\ \begin{array}{c}\text { marrow B19 } \\ \text { DNA }\end{array} & \text { B19 DNA } & \text { B19 IgM } & \text { B19 IgG } & \text { origin } & \end{array}$

Sweden

Acute Lymphoblastic Leukemia on chemotherapy (? total)

1

Acute Lymphoblastic Leukemia at onset (? total)

Non-Hodgkin's Lymphoma (? total)

Ewing's sarcoma (? total)

$n=59$

Acute Lymphoblastic Leukemia with anemia (50)

Acute Lymphoblastic Leukemia without anemia (34)

Acute Lymphoblastic Leukemia (24)

Acute Myeloblastic Leukemia (3)

Chronic Myeloblastic Leukemia (2)

Myelodysplastic Syndrome (2)

Acute Lymphoblastic Leukemia at onset (86)

Acute Lymphoblastic Leukemia on chemotherapy (31)

Acute Lymphoblastic Leukemia on chemotherapy (39)

Solid tumors, on chemotherapy (20)

Normal controls (30)

Hemolytic anemia, aplastic crisis (25)

Hemolytic anemia, no crisis (20)

Acute leukemia, on chemotherapy (20)

$\begin{array}{ccccc}11(22 \%) & & 13(26 \%) & 19(38 \%) & \text { Egypt } \\ 2(6 \%) & & 2(6 \%) & 15(44 \%) & \\ & & & & \\ 1(4.2 \%) & 4(16.7 \%) & 1(4.2 \%) & 10(41.6 \%) & \text { Germany } \\ 0 & 0 & 1(33.3 \%) & 1(33.3 \%) & \\ 0 & 0 & 0 & 0 & \\ 1(50 \%) & 1(50 \%) & 0 & 2(100 \%) & \end{array}$

Sweden

$6(7 \%)$

$12(39 \%)$

$\begin{array}{cccc}11(28 \%) & 0 & 26(67 \%) & \text { Egypt } \\ 5(25 \%) & 3(15 \%) & 10(50 \%) & \\ 0 & 0 & 18(60 \%) & \\ & & & \\ 6(25 \%) & 9(36 \%) & 14(56 \%) & \text { Egypt } \\ 0 & 1(5 \%) & 7(35 \%) & \\ 6(30 \%) & 7(35 \%) & 9(45 \%) & \end{array}$




\section{$9(45 \%) \quad 10(50 \%) \quad 8(40 \%)$}

Acute Lymphoblastic Leukemia on chemotherapy (48) Normal controls (20)

$9(20 \%)$

NT

$9(20 \%)$

0

$12(26.7 \%)$
0

$18(40 \%)$

$2(10 \%)$

$12(15.3 \%)$

$25(16.1 \%)$

$3(18.8 \%)$

$1(1.5 \%)$

Acute Lymphoblastic Leukemia at onset (65)

Acute Lymphoblastic Leukemia at onset (75)

Acute Lymphoblastic Leukemia at onset (40)

Normal controls (60)

Acute Lymphoblastic Leukemia at onset (18)

Acute Myeloblastic Leukemia (4)

Lymphoma (13)

Solid tumors (34)

Acute Lymphoblastic Leukemia on chemotherapy (45)

Acute Lymphoblastic Leukemia (30)

Acute Myeloblastic Leukemia (15)

Acute Lymphoblastic Leukemia at onset (40)

Acute Lymphoblastic Leukemia (24)

Acute Myeloblastic Leukemia (16)

Normal controls (20)

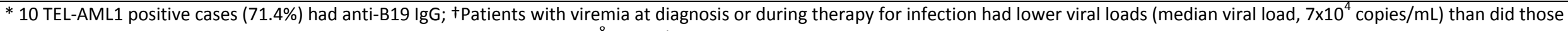
who became viremic during maintenance therapy (median viral load, $2 \times 10^{8}$ copies $/ \mathrm{mL}$ ). 
Table 4. Documented pathogenetic mechanisms important during parvovirus B19 infection which may be relevant to the pathogenesis of acute childhood leukemia.

\begin{tabular}{|c|c|c|c|c|c|c|c|c|c|c|}
\hline & $\begin{array}{l}\text { Local viral } \\
\text { replication† }\end{array}$ & $\begin{array}{l}\text { Erythroblast } \\
\text { apoptosis** }\end{array}$ & $\begin{array}{c}\text { NS1 } \\
\text { cytotoxicity } \neq\end{array}$ & $\begin{array}{c}\text { Immune } \\
\text { complex } \\
\text { deposition }\end{array}$ & $\begin{array}{l}\text { Autoantibody } \\
\text { production }+\dagger\end{array}$ & $\begin{array}{c}\text { HLA } \\
\text { associations§ }\end{array}$ & $\begin{array}{c}\text { Cytokine } \\
\text { upregulation } ¥ \ddagger\end{array}$ & $\begin{array}{l}\text { Persistence\& } \\
\text { reactivation } \uparrow \mathscr{T}\end{array}$ & $\begin{array}{l}\text { Methylation } \\
\text { of cancer } \\
\text { genes }\end{array}$ & References \\
\hline \multicolumn{11}{|c|}{ Common clinical manifestations ${ }^{*}$} \\
\hline TAC & + & + & & & & & & & & $72-74$ \\
\hline $\mathrm{EI}$ & + & + & + & + & & + & & & & $72,75-78$ \\
\hline Hydrops fetalis & + & + & & & & & & & & 79,80 \\
\hline Arthralgia/arthritis & & & $?$ & + & & + & $?$ & & & $74,75,77,81-86$ \\
\hline Chronic PRCA & + & + & & & & & & + & & 72,83 \\
\hline \multicolumn{11}{|l|}{$\begin{array}{l}\text { Less common clinical } \\
\text { manifestations }\end{array}$} \\
\hline Skin eruptions & + & & & & ? & & ? & + & & $74,75,77,81,84-86$ \\
\hline Meningoencephalitis & + & & & & & & + & & & $87-89$ \\
\hline Vasculitis & + & & & $?$ & ? & & $?$ & & & 90-97 \\
\hline Aplastic anemia/cytopenias & + & + & + & & & & + & + & & $72,81,98,99$ \\
\hline Acute leukemia & + & + & $?$ & & & ? & + & ? & + & $26,78,100$ \\
\hline
\end{tabular}

${ }^{*} \mathrm{TAC}=$ transient aplastic crisis; $\mathrm{El}=$ erythema infectiosum; PRCA = pure red cell aplasia.

†Local B19 replication occurs primarily in the erythroblasts, but also occurs in macrophages, myeloid cells, lymphocytes, hepatocytes, and dendritic epidermal and endothelial cells.

"Erythroblast apoptosis, mediated by the NS1 protein, occurs in TAC, El, and hydrops fetalis and probably also in PRCA and aplastic anaemia/cytopenias.

‡B19 NS1 cytotoxicity is thought to account for haematological abnormalities in El and cytopenias and possibly for arthralgia/arthritis.

IImmune complex deposition is thought to account for the rash of El, arthralgia, peripheral neuropathy and may contribute to other B19 associated skin rashes and

vasculitis.

††Anti-B19 VP1 lgG cross reacts with collagen II and keratin, which may be significant in the pathogenesis of arthritis and skin pathology, respectively. Antiphospholipid antibodies occur after B19 infection and may be important in the pathogenesis of autoimmunity.

$\S$ HLA-B49 and HLA-DRB1 ${ }^{*} 01,{ }^{*} 04,{ }^{*} 07,{ }^{*} 15$ and ${ }^{*} 16$ have been shown to be linked with symptomatic B19 infection.

++ Upregulation of human IL6, mediated by the NS1 protein, may be important in aplastic anaemia/cytopenias and B19 associated arthritis, and skin rashes.

IIPersistence of B19 is important in PRCA, may be important in B19 associated skin rashes, arthritis, CFS, RA, SLE, and vasculitis. 
Table 5. Protein sequence alignments encoded by different HLA-DRB1 alleles, showing the charge at the first hypervariable region, amino acids $9-13$, and associations with acute leukemia and symptomatic parovirus B19 infection, respectively.

\begin{tabular}{|c|c|c|c|c|c|c|}
\hline HLA-DRB1 allele & $\begin{array}{l}\text { Amino acids at } \\
\text { positions } 9-13\end{array}$ & $\begin{array}{l}\text { Charge for each } \\
\text { amino acid at } \\
\text { positions } 9-13^{*}\end{array}$ & Net charge & $\begin{array}{c}\text { Association with acute } \\
\text { leukemia } \\
\text { (Reference no.) }\end{array}$ & $\begin{array}{c}\text { Association with } \\
\text { symptomatic parvovirus } \\
\text { B19 infection } \\
\text { (Reference no.) }\end{array}$ & $\begin{array}{c}\text { Association with acute } \\
\text { leukemia in which B19 } \\
\text { virus was detected at } \\
\text { time of diagnosis of } \\
\text { leukemia (4 patients) } \\
\text { (Reference no.) }\end{array}$ \\
\hline
\end{tabular}

\begin{tabular}{|c|c|c|c|c|c|c|}
\hline *0101 & WQLKF & $n n n+n$ & + & 60 & 78 & \\
\hline *0301 & EYSTS & $-n n n n$ & - & & & \\
\hline *0401+ & EQVKH & $-\mathrm{n} n++$ & + & 57 & 78 & 26 \\
\hline *0701+ & WQGKY & $n n n+n$ & + & 57 & 78 & 26 \\
\hline$* 0801$ & EYSTS & $-n n n n$ & - & & & \\
\hline *0901+ (rare allele) & KQDKF & $+n-+n$ & + & 57 & & \\
\hline$* 1001$ & EEVKF & $--n+n$ & - & & & \\
\hline *1101 & EYSTS & $-n n n n$ & - & & & \\
\hline *1301 & EYSTS & $-n n n n$ & - & & & \\
\hline *1501 & WQPKR & $\mathrm{nnn}++$ & + & 58,59 & 89 & 26 \\
\hline *1601 & WQPKR & $n n n++$ & + & 58,59 & 89 & 26 \\
\hline
\end{tabular}

${ }^{*} n$, neutral

+ HLA-DRB4 is one of the expressed HLA loci, which exists only on haplotypes possessing HLA-DRB1*04, *07, and *09 
Table 6. Viruses that cause human cancer[106,107].

\begin{tabular}{|c|c|c|}
\hline Human oncovirus & Genome & Human cancer \\
\hline Epstein-Barr virus & DNA & $\begin{array}{l}\text { Burkitt's lymphoma, Hodgkin's lymphoma, Post-transplant lymphoproliferative } \\
\text { disease, Nasopharyngeal carcinoma }\end{array}$ \\
\hline Hepatitis B virus & DNA / RNA & Hepatocellular carcinoma \\
\hline Hepatitis C virus & RNA & Hepatocellular carcinoma \\
\hline Human T-lymphotropic virus & DNA / RNA & Adult T-cell leukemia \\
\hline Human papillomaviruses & DNA & Cancer of cervix, anus, penis, vulva, vagina and oropharynx \\
\hline Kaposi's sarcoma herpesvirus / Human herpesvirus 8 & DNA & Kaposi's sarcoma, primary effusion lymphoma, multicentric Castleman's disease \\
\hline Merkel cell polyomavirus & DNA & Merkel cell carcinoma \\
\hline
\end{tabular}

